\title{
COMPARISON OF CRYOSAT-2 AND ICESAT-2 ON WATER LEVEL MONITORING OF NAM CO LAKE
}

\author{
Haonan Zhao, Ruguo Xu, Gang Qiao* \\ College of Surveying and Geo-Informatics, Tongji University, 1239 Siping Road, Shanghai, China - \\ (1931986, 1832013, qiaogang) @tongji.edu.cn
}

Commission TCIII, WG III/9

KEY WORDS: Nam Co Lake, Tibetan Plateau, Water Level, Satellite Altimetry, ICESat-2, CryoSat-2

\begin{abstract}
:
There are more than 1,000 lakes $\left(>1 \mathrm{~km}^{2}\right)$ on the Tibetan Plateau and lake level is an important physical feature of lake changes. Lake level change is an important indicator to reflect changes of climate and environment in a certain area. The development of satellite altimetry has provided data support for the monitoring of lake level and effectively compensated for the deficiencies of traditional water level monitoring in alpine regions. In this study, the laser altimeter of ICESat-2 and the radar altimeter of CryoSat-2 are used to provide lake level of the Nam Co lake during the period of 2010-2020. The result showed that the standard deviation (SD) of ICESat$2(0.0895 \mathrm{~m})$ was lower than the SD of CryoSat $-2(0.2556 \mathrm{~m})$ and the months with higher SD values were mostly during the ice period of Nam Co lake. ICESat-2 had a considerably decreased measurement uncertainty. There are systematic differences in lake levels extracted by different altimetry satellites and the mean bias between ICESat- 2 and CryoSat- 2 was around $0.45 \mathrm{~m}$. After removing interaltimeter biases, the continuous lake levels from 2010 to 2020 were constructed. The inter-annual changes in lake levels were flat or even slightly decreased and the lake level has dropped by about $0.80 \mathrm{~m}$ in general. The water level generally reached the highest from September to October of the year in terms of intra-annual changes. Besides, temperature and precipitation changes were closely related to lake level tendency.
\end{abstract}

\section{INTRODUCTION}

The Tibetan Plateau (TP) is the region with the most widespread glaciers, except for Antarctica, Arctic, and Greenland, so it is referred to as the third pole (Zhang et al., 2015). The TP is also regarded as 'The Asia Water Tower', because it is the source of many major rivers that nourish hundreds of millions of people throughout western China and Aisa (Qiao et al., 2019). There are more than 1,000 lakes $\left(>1 \mathrm{~km}^{2}\right)$ on the TP, accounting for half of the total lakes in China (Zhang et al., 2019a; Ma et al., 2011). In the past 50 years, the TP has warmed rapidly, and its heating rate is about twice the global average (Lenssen et al., 2019), and most glaciers in the TP have exhibited a negative mass balance. In addition, precipitation has also shown a significant increase. Climate changes profoundly affect the physical properties of lakes, and in turn, lake changes can reflect changes of climate and environment in a certain area (Zhang et al., 2011). Lake level is an important physical feature of lake changes and the measurement of the lake level includes in-situ measurements and satellite altimetry. However, due to the high altitude, complex terrain and poor weather conditions of the TP, conventional hydrological observations are insufficient. In addition, even though there are in-situ data, the results are not comprehensive. For example, the level gauge is used to collect relative lake level, but it is damaged each year when the lake freezes, so some water level data will be missing (Zhang et al., 2019b). The development of remote sensing altimetry technique has provided data support for the monitoring of lake level and effectively compensated for the deficiencies of traditional water level monitoring in alpine regions (Song et al., 2015).

There are lots of satellite altimetry data to monitor lake levels, such as ERS-2(1995-2011), Envisat (2002-), ICESat(2003-2008),
CryoSat-2(2010-), ICESat-2(2018-)(Jiang et al., 2017; Crtaux et al., 2011). The laser altimeters of ICESat and ICESat- 2 are considered to have higher accuracy of better than $10 \mathrm{~cm}$ for lake surfaces and ICESat-2 altimetry has a dense lake coverage (Zhang et al., 2019b; Wang et al., 2013; Phan et al., 2012). However, the laser altimeters had the short temporal coverage that the operation time of ICESat was from 2003 to 2008 and ICESat-2 was launched in September 2018. As for the radar altimeters, CryoSat-2 altimetry can provide a finer footprint compared with traditional radar altimetry and has the long temporal coverage (Kao et al., 2019). In recent years, many scholars have studied the lake level changes on the TP, and their contents have mainly focused on the following two aspects. (1) Application of single satellite in lake level monitoring. For instance, Song et al. (2015) and Zhang et al. (2011) used the ICESat altimetry data over the period of 2003-2009 to monitor the lake levels on the TP. Jiang et al. (2017) used Cryosat-2 SARIn mode data to investigate recent lake level variations on the TP from 2010 to 2015. Medina et al. (2008) analyzed Lake Izabal (the biggest lake of Guatemala) level fluctuations using ENVISAT Radar Altimeter (RA-2). (2) Application of multisource satellite in lake level monitoring. In order to investigate the lake level variations at a long timescale, combination of several altimetry datasets is necessary and is helpful to analyze the characteristics and regular patterns of lake changes (Tseng et al., 2016; Liao at al., 2014). However, a continuous time series of lake level changes compiled by merging different altimetry data is uncertain due to the bias of different altimetry satellites. The methods for removing inter-altimeter biases include comparison with in situ measurements and other altimeters. Song et al. (2015) used in situ observations to remove the bias between ICESat and CroySat-2. Hwang et al. (2019) chose Jason-2

\footnotetext{
* Corresponding author
} 
altimeter as the basis to calibrate others. Kropacek et al. (2012) found the inter-instrument bias and chose ICESat as the standard to adjust the ENVISAT and GFO elevations by subtracting the constant value from all the measurements because of a good match of the ICESat data to the gauge measurement. Generally, altimeters with higher accuracy are used to remove interaltimeter biases because only a few lakes in TP have in situ observations.

Nam Co lake is the second largest lake and one of the "three holy lakes" on the TP (Adnan et al., 2019). Nam Co lake is basically not affected by human activities, so it is an ideal place for studying the lake change characteristics and climate conditions. In this paper, we analyzed lake level changes based on CryoSat2 radar altimetry and ICESat-2 laser altimetry during the period of 2010-2020. The focus of this paper is to remove inter-altimeter biases in order to obtain a more accurate continuous lake level and explore the relationship between temperature, precipitation, and lake level changes. The research will provide effective verification for the simulation of water balance in lake basins, and initially explore the relationship with climate factors.

\section{DATA AND METHOD}

\subsection{Study Area}

The study area (Figure 1) is Nam Co Lake $\left(30^{\circ} 30^{\prime}-30^{\circ} 55^{\prime} \mathrm{N}\right.$, $\left.90^{\circ} 16^{\prime}-91^{\circ} 03^{\prime} \mathrm{E}\right)$, the highest and second largest lake located in the southeastern TP, the north of Nyainqentanglha Mountains (Adnan et al., 2019). Nam Co lake is also known as heavenly lake in the Tibetan language and it stretches across two counties, Baingoin and Damxung (Li et al., 2014). Nam Co Lake is situated at the interaction of westerlines and Indian summer monsoon climatic systems and belongs to the plateau subfrigid monsoon semiarid climate zone. The dry and wet season are clear there, the wet season is from June to October and the dry season is from November to May next year. The water supply of Nam Co Lake mainly comes from precipitation and glacial melt water. The glacial melt water comes from the tributary in the southern part of the lake, namely from the Nyainqentanglha Mountains.

\subsection{Data}

2.2.1 CryoSat-2 altimetry data: CryoSat-2 is a radar altimetry satellite launched by European Space Agency (ESA) in 2010, characterized by three different modes, including low resolution mode (LRM), synthetic aperture mode (SAR) and synthetic aperture interferometric mode (SARIn) (Vieira et al., 2018). Compared to previously launched observation satellites, CryoSat-2 can provide along-track observations with a finer footprint of approximately 0.3 by $1.5 \mathrm{~km}$ and achieve centimeterlevel observation precision in complex terrain (Villadsen et al., 2015). In this paper, we used the SARIn mode and the baseline D level 2 (L2) dataset, which contain the longitude, the latitude, and the height of the surface for $20 \mathrm{~Hz}$ data.

\begin{tabular}{ccc}
\hline Satellite & CryoSat-2 & ICESat-2 \\
\hline Operation year & $2010-$ & 2018-present \\
present & $0.7 \mathrm{~m}$ \\
Resolution Along Track & $300 \mathrm{~m}$ & 91 \\
Repeat cycle/day & 369 & Laser \\
Type & Microwave & 122,819 \\
Footprint number & 15,208 & \\
\hline
\end{tabular}

Table 1. Parameters of altimetry satellites.
2.2.2 ICESat-2 altimetry data: ICESat-2 with the enhanced ATLAS sensor launched in September 2018 and it is superior to radar altimeter in data precision (Zhang et al., 2019b). ICESat-2 provides a dense coverage because it has six beams (Yuan et al., 2020). ICESat-2 contains three levels of data product (ATL01ATL21) and we used the ATL13 (level 3 product) which provides inland water elevation (Markus et al., 2017). The ATL13 product draws primarily from the level 2 ICESat-2 ATL 03 product and it is short segment lengths with a minimum 100 signal photons. The principal products contain along track surface height, significant wave height, subsurface attenuation, water depth and estimated vertical accuracy. Parameters of the two altimeter satellites are listed in the Table 1 and the satellite altimetry footprints are shown in Figure 1.

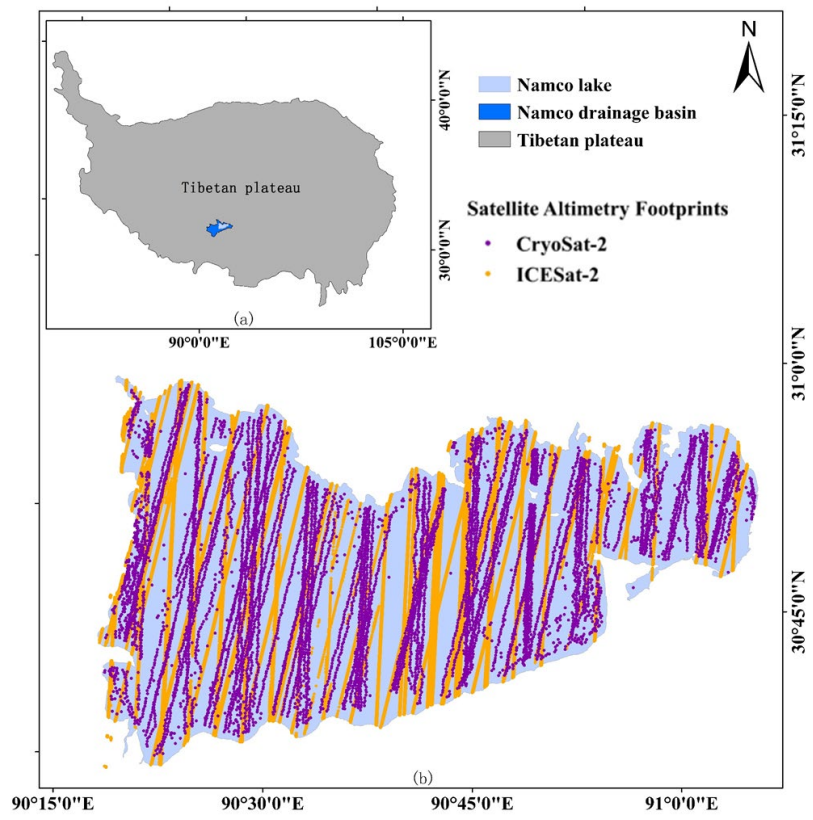

Figure 1. (a) Location of the Nam Co lake; (b) CryoSat-2 (purple point) and ICESat-2 (orange point) satellite altimetry footprints on the lake.

2.2.3 Hydroweb data: The Hydroweb data was from a hydrological project in Russia (Cretaux et al., 2011). This database provided water level variations using the data combined with ERS1, ERS2, Topex-Poseidon, GFO, ENVISAT, Jason1 and Jason 2 for about 150 lakes and reservoirs on the web site (http://hydroweb.theia-land.fr/hydroweb/). Water levels in the Hydroweb data were referenced to the GRACE GGM02C geoid. In this study, Hydroweb data was used as a reference data to validate the result of the lake level obtained from CryoSat- 2 and ICESat-2 altimetry data.

\subsection{Method}

2.3.1 The lake level extraction: The products of ATL13 and SARIn L2 have been corrected for elevation and we converted CryoSat-2 and ICESat-2 data to the WGS84 ellipsoid and EGM2008 Geoid, respectively. The first step of constructing a continuous time series of lake level is to select on-lake footprints of CryoSat-2 and ICESat-2 altimeters. The lake mask is obtained by the Muti-Band Water Index method based on the Landsat images and the specific methods are:

Step1: We converted the satellite altimetry data to shapefile file format based on latitude and longitude information and edited the coordinate system information. 
Step2: We constructed the buffer zone according to the size of ground footprints of different altimetry satellites to intersect with the lake mask.

Step3: All on-lake footprints were examined to remove outliers, because there are still some outliers in lake levels after the pervious steps. Removal of outliers can be applied through simple visual inspection of elevation profile and the method of 3 standard deviations (SD) that removes abnormal elevation values greater than 3 standard deviations due to the difference in turbidity and the scattering in the nearshore area (Zhang et al., 2011).

2.3.2 Merging of multi-source lake level data: After the lake level extraction, we removed inter-altimeter biases between ICESat-2 and CryoSat-2 to construct a continuous time series of the lake level. Because of the different satellites with different satellite orbit and revisit period, there will be different values for the altimeter observation system errors. Setting ICESat-2 altimetry data with higher accuracy as the reference, the water levels of CryoSat-2 satellite need to be compensated by a constant value. Constant compensation is obtained by averaging overlap interpolation between the altimetry data to be compensated and the reference altimetry data. The procedures of multi-source data processing and merging are illustrated in Fig. 2.

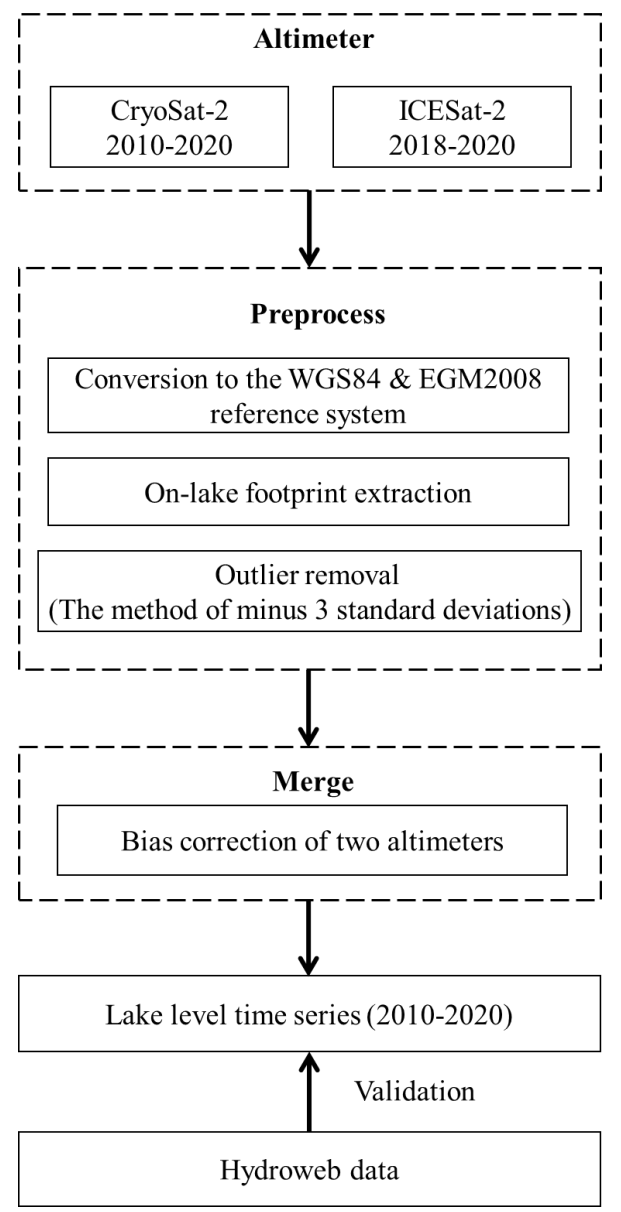

Figure 2. Flowchart of constructing lake-level time series.

\section{RESULT AND DISCUSSION}

\subsection{Evaluation of altimetry data}

There are many observations along the track for each observation time. The evaluation index of SD is used to calculate the uncertainty of the lake level at each observation time. We calculated the SD after outlier removal of the two altimetry satellites and found the SD of ICESat- $2(0.0895 \mathrm{~m})$ was lower than that of CryoSat-2 $(0.2556 \mathrm{~m})$, ICESat- 2 had a considerably decreased measurement uncertainty compared with CryoSat-2 (Figure 3). In addition, the months with higher SD values were mostly during the ice period of Nam Co lake.
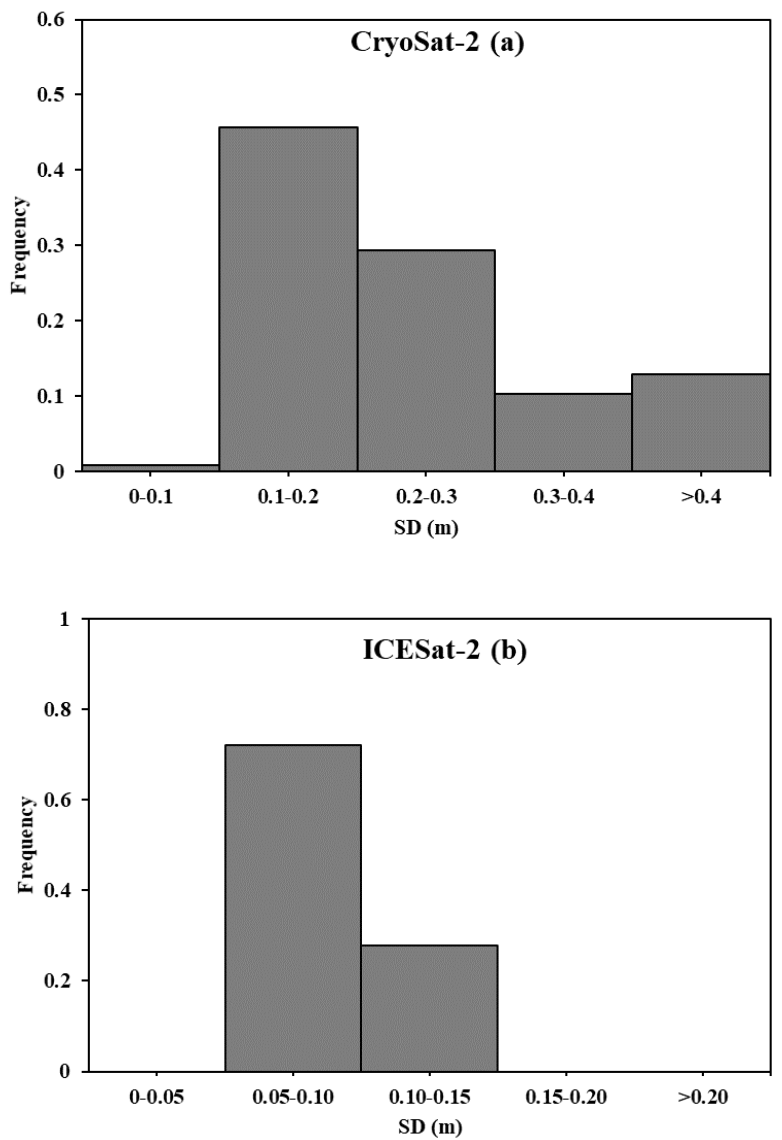

Figure 3. SD frequency distribution of CryoSat-2 (a) and ICESat-2 (b).

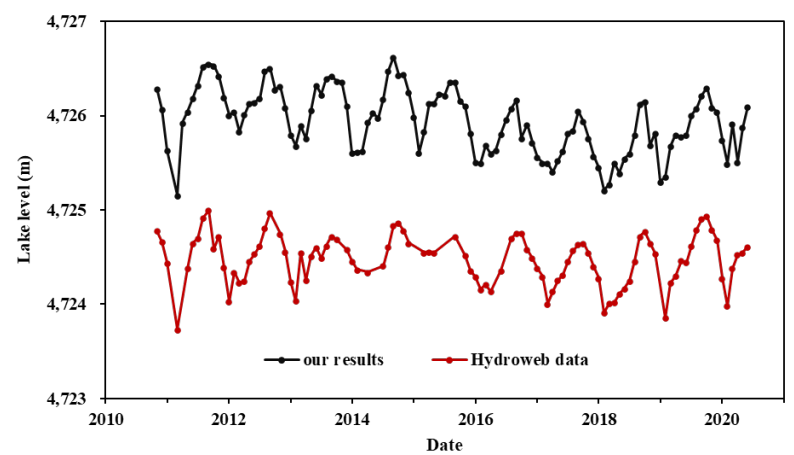

Figure 4. Comparison of lake levels derived from CryoSat-2 (black) and Hydroweb (red). 
In order to verify our study, the lake levels extracted by CryoSat2 altimetry satellite were compared with the Hydroweb data set from 2010 to 2020 . Hydroweb data was once used to verify field water levels on the Great Lakes and Lake Victoria in North America, and the accuracy was within a few centimeters of RMSE (Cretaux and Birkett, 2006). From Fig.4, the overall trends of the two data are basically similar, moreover the abrupt changes in lake water levels and the intra-annual variations are basically the same. For example, two data sets could well reflect the sudden rise in April 2006 and show the downtrend in October 2006. Obviously, the Hydroweb data is a little higher than satellite observations in this paper because of geoid varations and satellite system deviation (Cretaux et al., 2016). The water levels of the two data over a one-month interval are considered synchronous observations and they show a high correlation $(\mathrm{R}=0.82)$ at the $95.0 \%$ confidence level.

\subsection{Inter-annual changes of the lake level}

Due to the influence of system factors such as the use of instruments, running trajectories, and return cycles, there are systematic differences in lake levels extracted by different altimetry satellites. ICESat- 2 and CryoSat-2 altimetry data were overlapping during the period of 2018-2020 (totally 18 observation pairs). We used the constant compensation to remove the bias of CryoSat-2 based on ICESat- 2 and determined the mean bias between ICESat-2 and CryoSat- 2 was around $0.45 \mathrm{~m}$ where the maximum bias was $0.85 \mathrm{~m}$ and the minimum bias was $0.21 \mathrm{~m}$ (Figure 5). After removing inter-altimeter biases, we constructed continuous lake levels from 2010 to 2020 (Figure 6). The inter-annual changes in lake levels were flat or even slightly decreased and the lake level has dropped by about $0.80 \mathrm{~m}$ in general. The lake level was slightly decreased with a mean rate of $0.05 \mathrm{~m} /$ year from 2010-2020 according to CryoSat-2 altimetry data and the lake level was flat with a tendency value of 0.03 $\mathrm{m} /$ year from 2018-2020 according to ICESat-2 altimetry data.

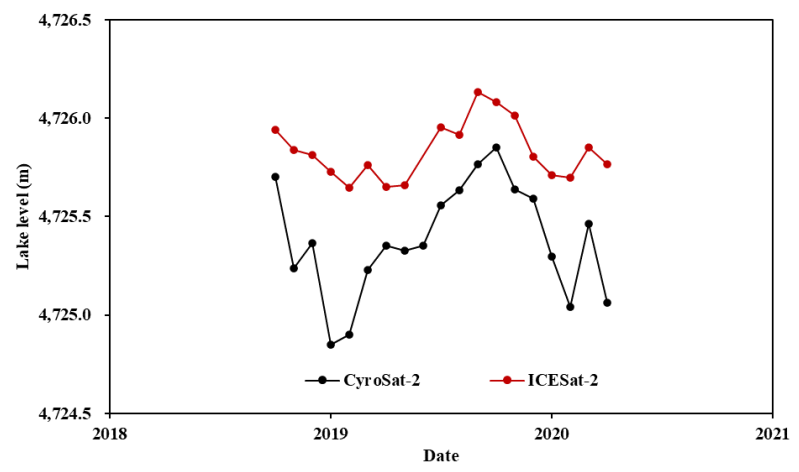

Figure 5. The lake level during the overlap period between ICESat-2 (red) and CryoSat-2 (black).

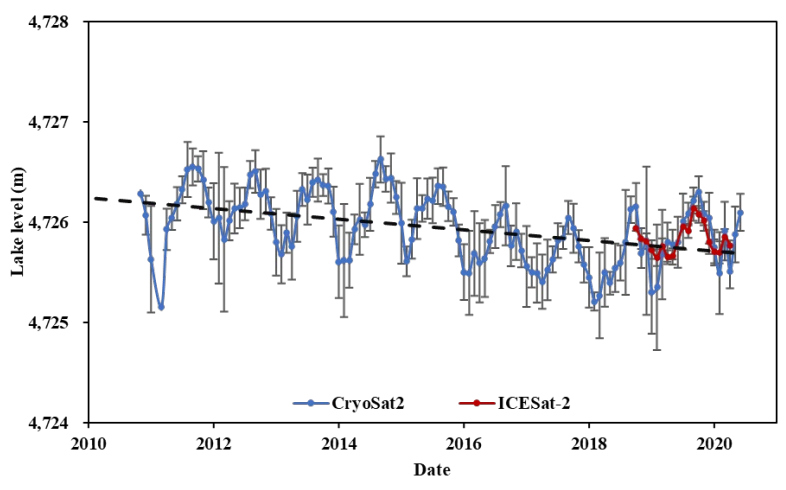

Figure 6. Time series of lake levels during 2010-2020.

\subsection{Intra-annual changes of the lake level}

In order to explore the intra-annual changes of the lake level, the lake levels of the past four years were used as a sample. As shown in Fig.7, the water level reaches the highest from September to October of the year. On the one hand, the precipitation is relatively large during this period. On the other hand, glacial meltwater flows into the Nam Co lake in the form of runoff, causing the lake level to rise. The lake level from February to March is the lowest time of the year. This is because the fact that there is less precipitation during this period and the lower temperature causes the lake to freeze.

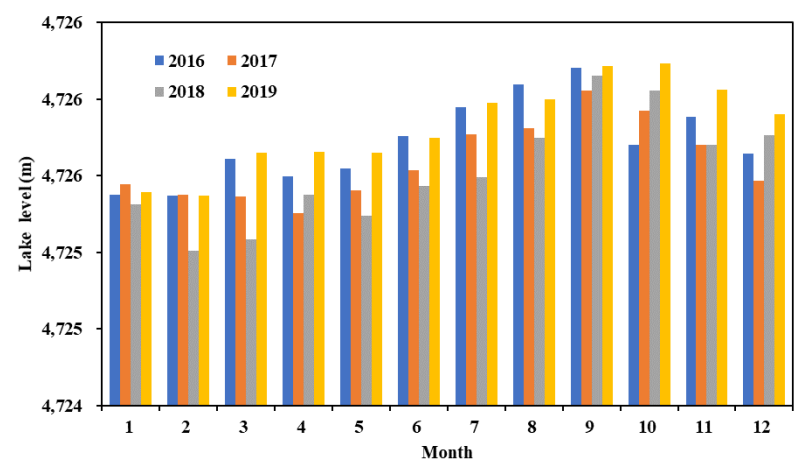

Figure 7. Intra-annual changes of lake level from 2016 to 2019.

\subsection{Temperature and precipitation changes associated with lake level tendency}

The changes of different lakes depend on their complex hydrological and climatic environment of the lake basin. After analyzing the inter-annual and intra-annual changes of the lake level in Nam Co lake, we used average temperature and precipitation data from Nagqu weather station for a simple analysis of the lake level trend and seasonal changes. The data of Nagqu weather station $\left(31^{\circ} 29^{\prime} \mathrm{N}, 92^{\circ} 04^{\prime} \mathrm{E}\right)$ was obtained from China Meteorological Data Network (http://data.cma.cn/en) from 2011 to 2019. The Nagqu weather station was chosen because it was closer to Nam Co lake, which was more representative of the weather conditions of the lake.

As shown in Fig.8, the precipitation displayed a flat or slightly decreased trend in general, which is consistent with the trend of the lake level. The precipitation reached the highest in July to September, while the lake level reached its maximum in September to October. The maximum value of precipitation can reach $100-200 \mathrm{~mm}$ per month, while the minimum value of precipitation is under $10 \mathrm{~mm}$ per month. Obviously, the peak of the lake level lagged the peak of the precipitation. The change of lake level is the result of the combined effect of replenishment and discharge. The continuous increase of precipitation from July to September will cause the imbalance of replenishment and discharge, and the lake level will rise. As shown in Fig.9, the average temperature had a high correlation with lake level variations. From 2011 to 2019, the overall annual temperature showed an upward trend, and the annual temperature also changed from negative to positive, with a mean rate of $0.13^{\circ} \mathrm{C}$ per year. The temperature is usually the highest in July, which can reach about $10{ }^{\circ} \mathrm{C}$ and the coldest month often occurs in January. In recent decades, global warming has accelerated the melting of glaciers and snow, which in turn accelerated evaporation, water transport and percolation into the subsurface 
(ground). The south of Nam Co lake is the Nyainqentanglha Mountains, which had a lot of glaciers. The glacial meltwater flows into Nam Co lake in a comb-like form, increasing the replenishment (Zhang et al., 2011). On the other hand, the rise in temperature also accelerated the loss of groundwater and the thawing of frozen soil. These factors have jointly caused the lake level changes.

In addition to precipitation and temperature, the glacier meltwater is an important factor in the lake expansion in previous studies. Li et al. (2014) used the glacier-melt model and Gridded Surface Subsurface Hydrologic Analysis model to investigate the glacier mass balance and found the glacial runoff contributed 5\% water balance in the Qugaqie Basin that is a sub-basin of the Namco Basin. Bolch et al. (2010) analyzed five glaciers around Nyainqentanglha Mountains and found these glaciers have been retreating around $10 \mathrm{~m}$ per year from 1970 to 2007 . However, the correlation coefficient between glacier meltwater and lake change was not high, so the glacial meltwater did not play a decisive role in lake changes (Song et al., 2014). Future research should conduct comprehensive, multi-site, continuous observation, and exploration models of the lake, revealing the specific reasons for the lake's response to climate and environmental changes.

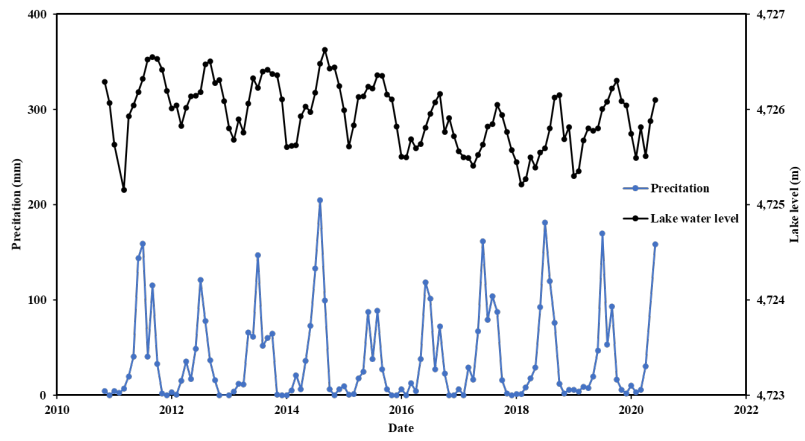

Figure 8. Precipitation changes associated with the lake level tendency.

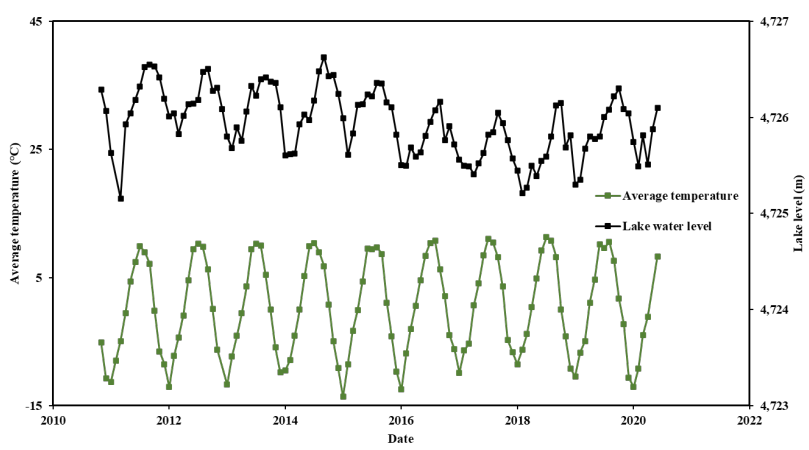

Figure 9. Temperature changes associated with the lake level tendency.

\section{CONCLUSION}

In this study, we have mainly done four tasks: (1) We evaluated ICESat-2 and CryoSat-2 altimetry satellites with SD values and Hydroweb data set. ICESat-2 had a considerably decreased measurement uncertainty compared with CryoSat- 2 and the months with higher SD values were mostly during the ice period of Nam Co lake. (2) We used the constant compensation method to remove the bias of CryoSat-2 based on ICESat-2 and determined the mean bias between ICESat- 2 and CryoSat- 2 was around $0.45 \mathrm{~m}$. (3) After combining the two altimeters, we analyzed the inter-annual and intra-annual changes of the lake level. The inter-annual changes in lake levels were flat or even slightly decreased and the lake level has dropped by about 0.80 $\mathrm{m}$ during the period of 2010-2020. In terms of intra-annual changes, the water level generally reached the highest from September to October of the year. (4) Finally, we initially explored the relationship between lake levels and climate factors. Temperature and precipitation data were used for a simple analysis of the Nam Co lake.

This study focused on the qualitative analysis of lake level changes, which is insufficient to accurately analyze the impact of climate change on lake levels. More quantitative analysis of lake level changes needs to be achieved in the future and more climate and cryosphere factors should be considered, such as evaporation, glacial meltwater, snow meltwater, groundwater seepage, and frozen ground thawing. In addition, lake level can be combined with area to estimate lake water volume. The lake area extraction can be carried out using the Google Earth Engine (GEE) platform, which has changed the traditional method and provided a new means for obtaining long time series of lake area quickly. Then lake water volume is the integral of the relationship between lake area and water level. The lake level, area, and water volume will better reflect the lake changes and provide a scientific basis for sustainable development of water resources and ecological environment protection on the Tibetan Plateau.

\section{ACKNOWLEDGEMENTS}

This work was supported by the National Key Research and Development Program of China (2017YFA0603102 and 2017YFB0503502), the National Science Foundation of China (41771471, 41941006, and 91547210).

\section{REFERENCES}

Adnan, M., Kang, S., Zhang, G., Saifullah, M., Anjum, M.N., Ali, A.F., 2019. Simulation and Analysis of the Water Balance of the Nam Co Lake Using SWAT Model. Water, 11(7), 1383.

Bolch, T., Yao, T., Kang, S., Buchroithner, M.F., Scherer, D., Maussion, F., Huintjes, E., Schneider., C., 2010. A glacier inventory for the western Nyainqentanglha Range and the Nam Co Basin, Tibet, and glacier changes 1976-2009. Cryosphere, 4(3), 419-433.

Cretaux, J., Birkett, C., 2006. Lake studies from satellite radar altimetry. Comptes Rendus Geoscience, 338, 1098-1112.

Crétaux, J. F., Jelinski, W., Calmant, S., Kouraev, A., Vuglinski, V., Bergé-Nguyen, M., Gennero, M.C., Nino, F., Abarca-del-Rio, R., Cazenave, A., Maisongrande, P., 2011. SOLS: A lake database to monitor in the near real time water level and storage variations from remote sensing data. Advances in Space Research, 47(9), 1497-1507.

Cretaux, J.F., Abarca-del-Rio, R., Berge-Nguyen, M., Arsen, A., Drolon, V., Clos, G., Maisongrande, P., 2016. Lake Volume Monitoring from Space. Surveys in geophysics, 37, 269-305.

Hwang, C., Cheng, Y., Yang, W., Zhang, G., Huang, Y., Shen, W., Pan, Y., 2019. Lake level changes in the Tibetan Plateau 
from Cryosat-2, SARAL, ICESat, and Jason-2 altimeters. Terrestrial Atmospheric and Oceanic Science, 30(1), 33-50.

Jiang, L., Nielsen, K., Andersen, O. B., Bauer-Gottwein, P., 2017. Monitoring recent lake level variations on the Tibetan Plateau using CryoSat2 SARIn mode data. Journal of Hydrology, 544, 109-124.

Jiang, L., Andersen, O.B., Nielsen, K., Zhang, G., BauerGottwein, P., 2019. Influence of local geoid variation on water surface elevation estimates derived from multi-mission altimetry for Lake Namco. Remote Sensing of Environment, 221, 65-79.

Kao, H., Kuo, C., Tseng, K., Shum, C., Tseng, T., Jia, Y., Yang, T., Ali, T., Yi, Y., Hussain, Y., 2019. Assessment of Cryosat-2 and SARAL/AltiKa altimetry for measuring inland water and coastal sea level variations: A case study on Tibetan Plateau lake and Taiwan Coast. Marine Geodesy, 42(4), 327-343.

Kropacek, J., Braun, A., Kang, S., Feng, C., Ye, Q., Hochschild, V., 2012. Analysis of lake level changes in Nam Co in central Tibet utilizing synergistic satellite altimetry and optical imagery. International Journal of Applied Earth Observation and Geoinformation, 17(SI), 3-11.

Lenssen, N.J.L., Schmidt, G.A., Hansen, J.E., Menne, M.J., Persin, A., Ruedy, R., Zyss, D., 2019. Improvements in the GISTEMP Uncertainty Model. Journal of Geophysical Research-Atmospheres, 124(12), 6307-6326.

Li, B., Yu, Z., Liang, Z. and Acharya, K., 2014. Hydrologic response of a high altitude glacierized basin in the central Tibetan Plateau. Global and Planetary Change, 118, 69-84.

Li, L., Li, J., Yao, X., Luo, J., Huang, Y., Feng, Y., 2014. Changes of the three holy lakes in recent years and quantitative analysis of the influencing factors. Quaternary International, 349 339-345.

Liao, J., Gao, L., Wang, X., 2014. Numerical Simulation and Forecasting of Water Level for Qinghai Lake Using MultiAltimeter Data Between 2002 and 2012. IEEE Journal of Selected Topics in Applied Earth Observations and Remote Sensing, 7(2), 609-622.

Ma, R., Yang, G., Duan, H., Jiang, J., Wang, S., Feng, X., Li, A., Kong, F., Xue, B., Wu, J., Li, S., 2011. China's lakes at present: Number, area and spatial distribution. Science China, 54(2), 283289.

Markus, T., Neumann, T., Martino, A., Abdalati, W., Csatho, B., Farrell, S., Fricker, H., Gardner, A., Harding, D., Jasinski, M., Kwok, R., Magruder, L., Lubin, D., Luthcke, S., Morison, J., Nelson, R., Neuenschwander, A., Palm, S., Popescu, S., Shum, C.K., Schutz, B.E., Smith, B., Yang, Y., Zwally, J., 2017. The Ice, Cloud, and land Elevation Satellite-2 (ICESat-2): Science requirements, concept, and implementation. Remote Sensing of Environment, 190, 260-273.

Medina, C.E., Gomez-Enri, J., Alonso, J.J. and Villares, P., 2008. Water level fluctuations derived from ENVISAT Radar Altimeter (RA-2) and in-situ measurements in a subtropical waterbody: Lake Izabal (Guatemala). Remote Sensing of Environment, 112(9), 3604-3617.

Phan, V., Lindenbergh, R., Menenti, M., 2012. ICESat derived elevation changes of Tibetan lakes between 2003 and 2009.
International Journal of Applied Earth Observation \& Geoinformation, 17(SI), 12-22.

Qiao, B., Zhu, L., Yang, R., 2019. Temporal-spatial differences in lake water storage changes and their links to climate change throughout the Tibetan Plateau. Remote Sensing of Environment, $222,232-243$

Song, C., Huang, B., Richards, K., Ke, L., Vu, H.P., 2014. Accelerated lake expansion on the Tibetan Plateau in the 2000s: Induced by glacial melting or other processes? Water Resources Research, 50(4), 3170-3186.

Song, C., Ye, Q., Cheng, X., 2015. Shifts in water-level variation of Namco in the central Tibetan Plateau from ICESat and CryoSat-2 altimetry and station observations. Science Bulletin, 60(14), 1287-1297.

Tseng, K., Chang, C., Shum, C., Kuo, C., Liu, K., Shang, K., Jia, Y., Sun, J., 2016. Quantifying freshwater mass balance in the central Tibetan plateau by integrating satellite remote sensing, altimetry, and gravimetry. Remote Sensing, 8(6), 441.

Vieira, T., Joana Fernandes, M., Lazaro, C., 2018. Analysis and retrieval of tropospheric corrections for CryoSat-2 over inland waters. Advances in Space Research, 62(6), 1479-1496.

Villadsen, H., Andersen, O.B., Stenseng, L., Nielsen, K., Knudsen, P., 2015. CryoSat-2 altimetry for river level monitoring - Evaluation in the Ganges-Brahmaputra River basin. Remote Sensing of Environment, 168, 80-89.

Wang, X., Gong, P., Zhao, Y., 2013. Water-level changes in China's large lakes determined from ICESat/GLAS data. Remote Sensing of Environment, 132, 131-144.

Yuan, C., Gong, P., Bai, Y., 2020. Performance assessment of icesat-2 laser altimeter data for water-level measurement over lakes and reservoirs in china. Remote Sensing, 12(5), 770.

Zhang, B., Wu, Y., Zhu, L., Wang, J., Li, J., Chen, D., 2011. Estimation and trend detection of water storage at Nam Co Lake, central Tibetan Plateau. Journal of Hydrology, 405(1-2), 161-170.

Zhang, G., Xie, H., Kang, S., Yi, D., Ackley, S.F., 2011. Monitoring lake level changes on the Tibetan Plateau using ICESat altimetry data (2003-2009). Remote Sensing of Environment, 115(7), 1733-1742.

Zhang, G., Yao, T., Xie, H., Wang, W., Yang, W., 2015. An inventory of glacial lakes in the Third Pole region and their changes in response to global warming. Global and Planetary Change, 131, 148-157.

Zhang, G., Luo, W., Chen, W., Zheng, G., 2019a. A robust but variable lake expansion on the Tibetan Plateau. Science Bulletin, 64(18), 1306-1309.

Zhang, G., Chen, W., Xie, H., 2019b. Tibetan Plateau's Lake Level and Volume Changes from NASA's ICESat/ICESat-2 and Landsat Missions. Geophysical Research Letters, 46(22), 1310713118. 